UVITED STATES DEPARTMENT OF TUE INTERIOR

GEOLOGICAL SURVEY

MODERN CHRYSOMONAD CYSTS FROM

FALLEN LEAF LAKE, ELDORADO COUNTY, CALIFORNIA

\author{
by \\ David P. Adam \\ and \\ Albert D. Mahood \\ OPEN-FILE REPJRT \\ $80-793$
}
This resort is oreliminary and has not been reviewed for conformity with
U. S. Geological Survey editorial standards
or stratigraohic nomenclature


INTRODUCTION

This report is one of a series illustrating siliceous cysts fron various localities. Although these cysts have been known for many years, they are so small that they cannot be observed in detail with ootical microscopes. The recent development of the scaling electron microscope (SEM) has made possible much more detailed observations of the external features of these cysts, but as yet relatively few forns have been recorded in this way.

4 major difficulty is taxonomic confusion. Many and oerhoos all of these cysts are the resting stages of various alqae of the phylun chrysophyta; they will be referred to in the rest of this report as chrysomonad cysts, although other grouos in adjition to the Chrysomonadinae may be reoresented. yodern forms are found prinarily in fresh water, and numerous authors have reosrted chrysomonad cysts from Holocene sediments (for exanple, see Nygaard, 1956). Older fossils have been recovered nostly from narine desosits, and are known as archaeomonads: whether the two groups are as distinct as this terminology suggests is not clear.

For an introduction to the literature on chrysomonad cysts and siliceous algal scales, the reader is referred to Adam and Mahood (1979b), a preliminary annotated bibliograohy on the subject. 
The fossil archaeomonads have been described and named entirely on the basis of their cysts. This is not advisable with modern forns, because the cysts are the remains of one stage of the life cycle of alqae that presunably already have legitimate taxonomic names. sroper cyst nomenclature therefore depends on establishing which cysts are produced by which algae. At the monent, we have only a very limited knowledge of the forns that exist, and almost no knowledge of the shycological pedigrees of the various forms.

The present work is directed towards exoanding our knowledge of the various cyst forns and their geozraphic and environmental distributions. Taxonomic oroslems are ignored, and the various cyst forms are simoly given numbers, which have been assigned arbitrarily. These numbers are consistent throughout all reports in this series, and are jeing used to tabslate where the various forms occur. (A list of the orevious reoorts in this series is given in Appendix 4). The aporoach used has been that of "solitting", as opposed to "lumping"; it may well be desirable to lump together many of the forms described here when more is known abost them.

The SEn photographs are the nost imoortant part of this paser, and no attempt has been nade to reduce them to words. Supporting data have been olaced in the 
captions. Samole oreoaration techniques are generally the same as those used for preparing diatom samples: details may be found in Yahood and Adam (1979b).

The purpose of these initial reoorts is to provide Drinary Jocumentation of the occurrence of particular cyst forms at jarticular localities, ant to provide a neans by which the SEM ohotographs of the cysts may be olaced in 3 permanent depository. counts of the relative abundance of the various forms and interoretations of their significance have not yet been attenpted, but must await a more complete understanding of the range of cyst morohologies.

we have illustrated all of the distinctive cyst forns found in the sample, using the best available photograpus. In some instances we have included more than one ohotograoh of a given form, but we have not inclsded ail of the photographs we have taken.

vegatives of the olates for this report are on deossit at the USGS Photo Library, and prints can be obtained (at your expense) by writing to:

U. S. Geological Survey Library

Proto Library

Stop 914

Sox 25406 . Denver Federal Center

Denver. Colorado 80225 


\section{SITE DESCRIPTION}

Fallen Leaf Lake is located just south of Lake Tahoe at an elevation of $1944 \mathrm{~m}$. The samole studied for this report was collected by R. H. Fuller at his station 2 on 24 July, 1974, in $70 m$ of water about $153 \mathrm{~m}$ from the south end of the lake (fuller, 1975). Water samples were taken from the lake at several tines during the year for fuller's study, and he reports various chrysophyte algae from the lake, including chrysochrzmuliza Qarya, chcysojkzs so.. Dinobryou bavacisul (both cysts and active stages). Diceras (Bcitcichia) so.. and Qiseras shodati. He also presented chemical data for the lake: it is nearly neutral. with $\mathrm{pH}$ values usually rangina between 6.5 and 7.5. However, $\mathrm{DH}$ values tended to rise during the sumner, and by 21 october, 1974, a pH of 8.88 was recorded 3 t a depth of $9 \mathrm{~m}$. 


\section{- REFERENCES CITED}

Adan. David P.. and Mahoot, Albert Y.. 1979b, A oreliminary working bibliography on siliceous alqal cysts and scales. U. S. Seological Survey oden-file २ eport No. 79-1215, 34 p.

Fuller. Richard H.. 1975, Selected water-quality data from Fallen Leaf Lake. Eldorado County. California. June through October 1974: U. S. Geological Survey Joentfile Report. 38 D.

Vygard, junnar, 1956. Ancient and Recent flora of diatons and Chrysophyceae in Lake Gribso. in Bera. <aj, and petersen. I. C.. eds.. Studies on the humic acid Lake Gribsb: Folia Linnologia Scandinavica. No. 3. p. $32-94,12$ plates. 


$$
\begin{aligned}
& \text { Fallen Leaf Lake; Plate } A \\
& \text { scale bar }=3 \text { microneters }
\end{aligned}
$$

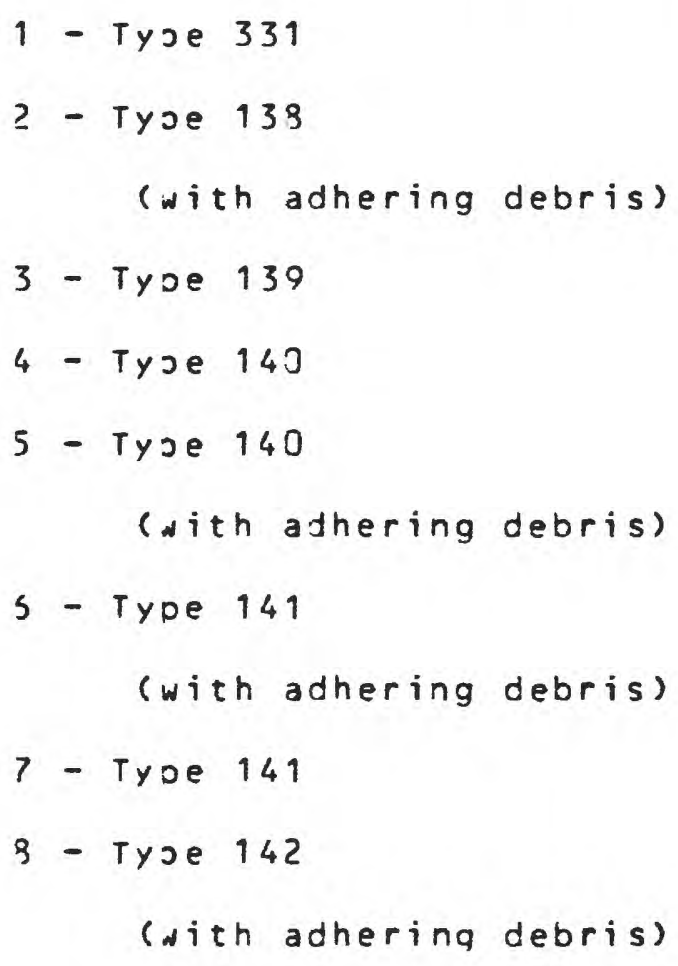


Fallen Leaf Lake - Plate A
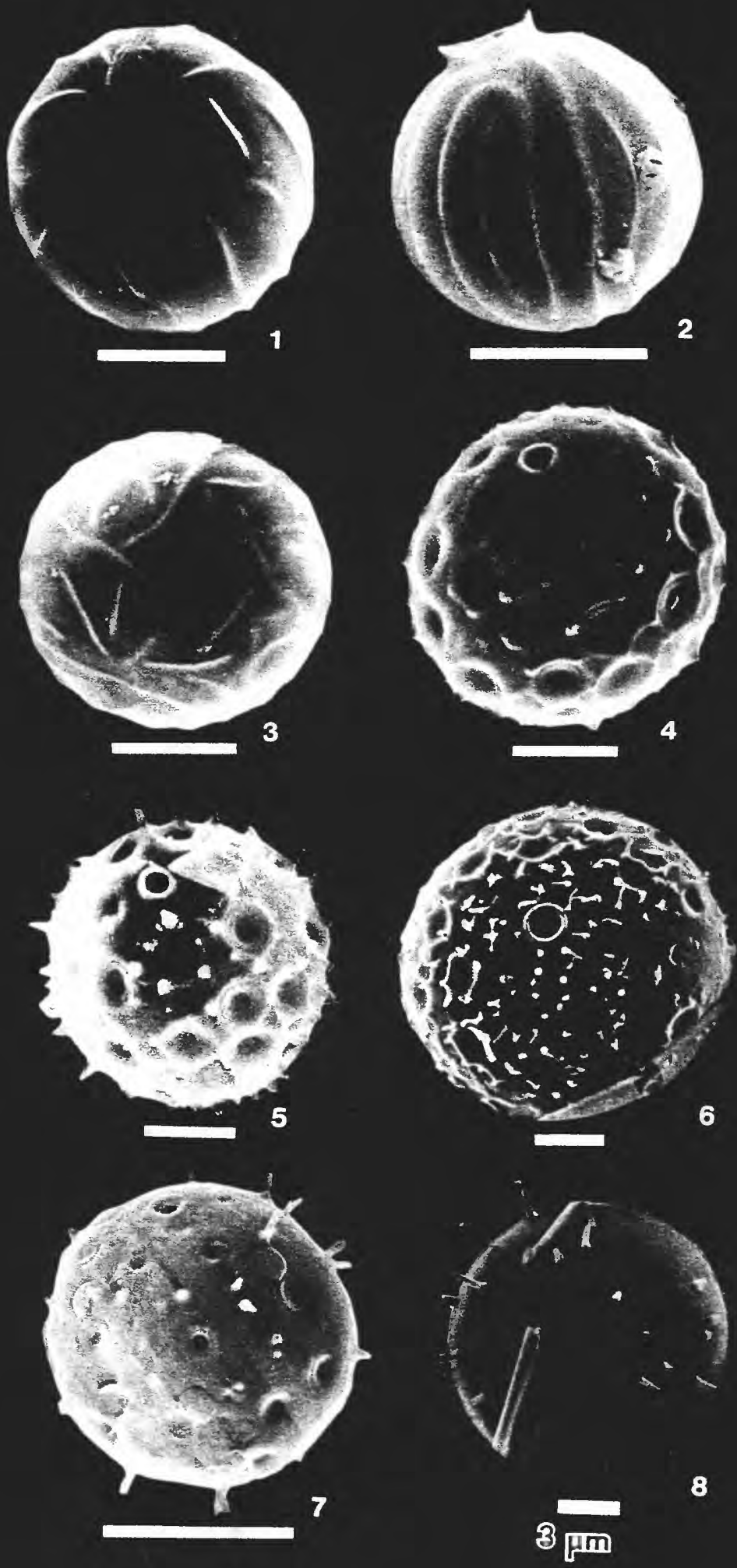

Adam \& Mahood - UsGs Open-File Report 80-798 
Fallen Leaf Lake, Plate $B$

scale bar $=3$ nicrometers

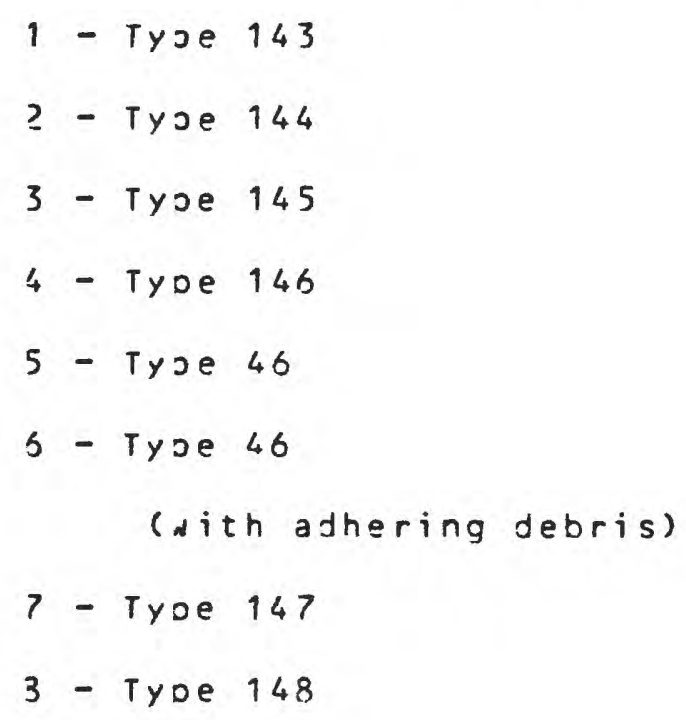




\section{Fallen Leaf Lake - Plate B}
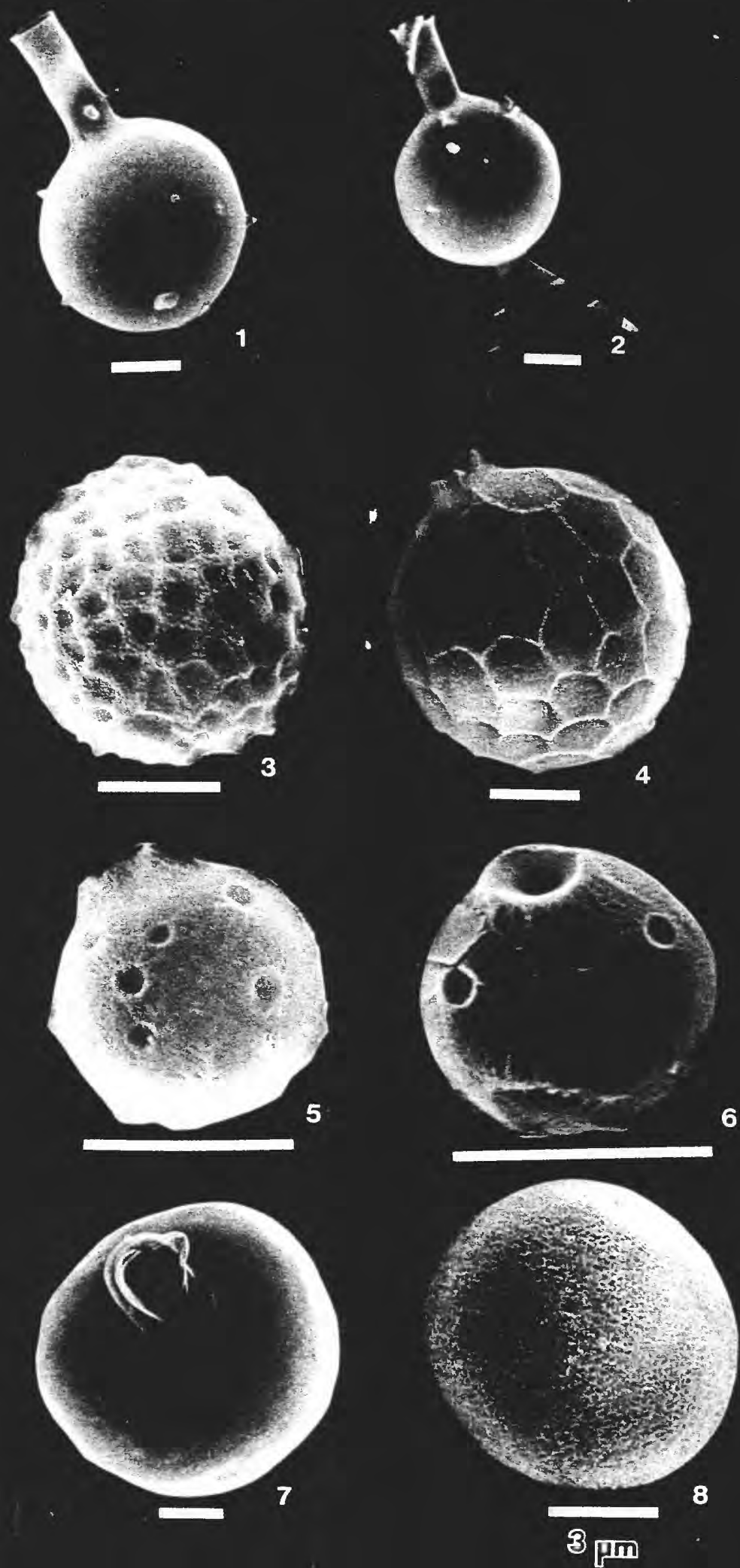

Adam \& Mahood - USGS Open-File Report 80-798 


\section{APPENDIX A}

PREVIOUS REPORTS IN THIS SERIES

$-9-$ 
lahood. Albert D.. and Adan. David P.. 1979a, Late Pleistocene chrysomonad cysts fron core 7 . Clear Lake. Lake county. California: U. S. Geological Survey Open-file Report vumber 79-971, 11 p.. 4 olates. Defines types 1 through 44 .

Adame David P... and Mahood, Albert D.. 1979a, A praliminary annotated bibliography on siliceous algal cysts and scales: U. S. Geological Survey 0oen-file Report Number 79-1215, 34 o.

lahooj, Albert D.. and Adam, David P.. 1979b. Techniques used for the cleaninge concentration. and observation of chrysomonad cysts from sediments: $U$. S. Geological Survey open-file Reoort Number 79-1431, $5 \mathrm{p}$.

Ajame David P.. and Mahood, Albert D.. 1979b. Chrysomonad cysts from Upper Echo Lake. Eldorado County. California: U. S. Geological Survey Open-file Report Nunber 79-1461, 21 p. +12 plates.

Ajam, David P... and Yehringer. Peter J.. Jr.. 1980. Modern and Holocene chrysomonad cysts from Lost Trail Dass Bog. Montana: U. S. Geological Survey 0jeר-file Reoort Number $80-797,13 \mathrm{p.}+5$ plates. 